\title{
Learning Patterns for the Students of Shoubak University College
}

\author{
Haroon. M. Tawarah ${ }^{1}$, Omar. M. Mahasneh",* \\ ${ }^{1}$ Department of Basic and Applied Science, Al- Shobak University College, AL-Balqa Applied University, Jordan \\ ${ }^{2}$ Department of Basic and Applied Science, Faculty of Shobak University College, AL-Balqa Applied University, Jordan
}

Received June 25, 2020; Revised August 13, 2020; Accepted August 25, 2020

\begin{abstract}
Cite This Paper in the following Citation Styles
(a): [1] Haroon. M. Tawarah, Omar. M. Mahasneh, "Learning Patterns for the Students of Shoubak University College," Universal Journal of Educational Research, Vol. 8, No. 10, pp. 4700 - 4706, 2020. DOI: 10.13189/ujer.2020.081039.
\end{abstract}

(b): Haroon. M. Tawarah, Omar. M. Mahasneh (2020). Learning Patterns for the Students of Shoubak University College. Universal Journal of Educational Research, 8(10), 4700 - 4706. DOI: 10.13189/ujer.2020.081039.

Copyright $\bigcirc 2020$ by authors, all rights reserved. Authors agree that this article remains permanently open access under the terms of the Creative Commons Attribution License 4.0 International License

\begin{abstract}
The two researchers noticed through their teaching repeatedly that the students were not interacting during the lectures, so this study aimed to identify the learning Patterns of students at Al-Shoubak University College. The researchers used the descriptive method (educational survey). To achieve the objectives of the study, a questionnaire was developed, consisting of (20) items distributed in four Patterns of learning, namely visual, auditory, Kinesthetic, reading and writing, according to the model of the scientist Fleming. The sample consisted of (216) male/female students. The results of the study showed that the level of the following learning Patterns: (Kinesthetic, visual, reading and writing) have achieved a high degree. In addition, Shobak University College students prefer the Kinesthetic learning Patterns where it got the highest mean which is (2.49), and the learning Pattern, Auditory, has achieved the lowest mean which is (2.33) with Average degree. There are no statistically significant differences at the level of alpha significance $=0.05$ among the level of learning patterns and students due to the gender variable. In light of the results of the study, the two researchers recommended that the faculty members in universities should observe the Patterns of students learning during the teaching and evaluation process.
\end{abstract}

Keywords Learning Patterns, Al-Shoubak University College, Students of Shoubak University College, Curriculum and Instruction

\section{Introduction}

The primary objective of education in universities is to create a generation with knowledge, skills and attitudes and consistent with its discipline. According to modern educational theories, the student is considered the focus of the educational process, and therefore the teaching and evaluation processes in universities must be appropriate to the students' favorite learning Patterns in order to achieve the desired benefit. Dunn and Dunn (1993) defined the learning Pattern as the method by which the learner tries to focus on the information and retrieve it. As for Kinsella (1994), it was defined as the individual's preferred and continuous method of dealing with information and skills and retrieving them.

Jaber and Al-Qura'an (2004) stated that the US Schools Union Administration defined the learning Pattern as the best method for students to learn. As for Fleming, he defined the learning Pattern as the method that makes the student receive, arrange, organize, record, code, merge, preserve and retrieve information when needed. In light of the previous definitions, it is possible to define the learning Pattern, as it is the preferred method or manner for each student during the learning process, which makes him feel comfortable and not being annoyed and through which he achieves the desired benefit.

\section{The Theoretical Literature Review}

After the researchers reviewed the theoretical literature 
on learning styles, we will list them Several models have been emerged for learning Patterns as mentioned by (Jaber and Al-Qura'an, 2004), (McCarthy, 1987), (Zhenhui, 2002), (Al-Mahasneh, Ayasrah, Yahyaa, Al-Kriemeen and Al-Swalha, 2020) and (Jester, 1998) as follows:

- David Kolb's Experiment-Focused Model four learning Patterns are (Convergence, Divergence, Assimilation, and Accommodation).

- The Honey and Mumford Model (1990). They adapted David Kolb's model to administrative work so that learning Patterns are divided into (Activist, Reflector, Theorists and Pragmatist).

- $\quad$ Gregorc Mediation Ability Model (1991). It includes two main pathways so that the individual can interact with life: perception and processes, whether concrete or abstract.

- McCarthy 4 MAT Model Learning Patterns are divided into four Patterns, namely: Imaginary Learner, Analytical Learner, Logical Learner and Dynamic Learner.

- Dunn and Dunn Model (1991) each student has his own method of learning Patterns are divided into the following: (Environmental, Emotional, Social, Physical and Psychological).

- Hill Mental Patterns Model. Mental Pattern is considered, according to (Hill), the method by which the individual is capable to receive and process the information. The Professional-Pattern consists of four dimensions: (Codes, Cultural Limitations, Conclusion Forms and Educational Memory).

- Anthony Gregorc Model the individual has sensory characteristics and organizational capabilities that are represented in four Patterns: (Concrete Sequential, Abstract Sequential, Abstract Random and Concrete Random

- Herman Model. Learning Patterns have been divided, according to the function of the brain, into the following: internal learning (the right upper part of the brain), external (the left upper part of the brain), interactive (the right lower part of the brain) and procedural (the left lower part of the brain). (Steyn and Marce, 2003)

- Carl Jung Model. Learning Patterns have been classified into the following: (Feeling, Thinking, Sensation and Intuition).

- $\quad$ Neil Fleming Model which is also called (VARK) Model or Theoretical and Educational, Model Learning Patterns have been classified into the following: (visual, Aural, Kinesthtic and Read/Write). It has been developed based on the attitudes and preferences of the students each student has his own method of receiving and understanding the information. This model consists of four Patterns as they are illustrated by figure (1):

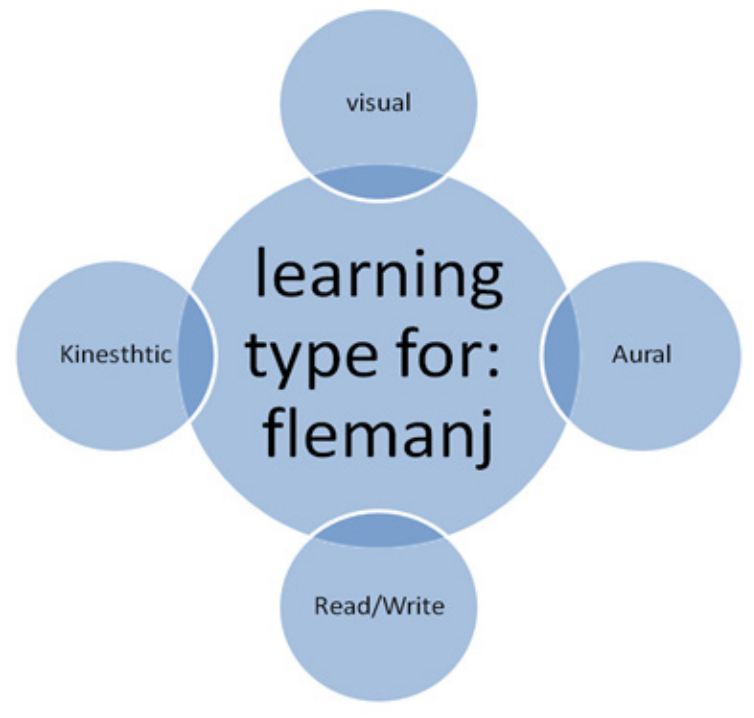

Figure 1. Learning Patterns According to the Scientist Neil Fleming

Figure 1 illustrates learning Patterns by the scientist Fleming as follows:

- Visual Learning Pattern: The learner relies on the sense of sight with what it contains to translate what he sees as appropriate.

- Auditory Learning Pattern: The learner relies on the sense of hearing to understand learning processes and interact with them.

- Reading/Writing Learning Pattern: the individual learns better by reading or writing ideas.

- Kinaesthetic Learning Pattern: the individual learns through (work) and uses all the senses in the learning process.

The two researchers note from the above that some models of learning Patterns focused on the students' use of the senses in the learning process and accordingly they were divided as the model of the scientist Neil Fleming, while others divided them based on the learning aspects of the learner such as the model of the scientist Dunn and Dunn). Some models divide learning Patterns according to the learner's role in the learning process as the McCarthy 4 MAT Model. Based on the principle of individual differences, each student prefers one or more Pattern of learning, and therefore educators must pay attention to knowing the appropriate learning Patterns for students before teaching and evaluation processes, which reflects positively on the educational learning process. Increasing student achievement and creating positive attitudes toward learning are related to the degree of compatibility between the teacher's teaching Pattern and students' learning Pattern. Therefore, the teacher must strive to choose learning Patterns that are consistent with the students' realities. As one of the criteria that plays an important role in the teacher's choice of teaching strategy and assessment methods is the learning Pattern, which makes the learning process enjoyable and attractive and contributes to making 
the learner a focus of the educational learning process (Jaber and Al-Qur'an, 2004; Mahasneh, Al-tawarah and Al-Msadeen, 2013; Mahasneh and Murad, 2014; Mahasneh, Al-Tawarah and Al-Hawartheh, 2017; Mahasneh, 2020a; Mahasneh, 2020b; Mahasneh, 2020c; Tawarah and Mahasneh, 2020; Almseidein and Mahasneh, 2020).

The two researchers found studies related to the subject of the study as Abu Al-Nadi and Al-Shammari (2016) conducted a study aimed at revealing the preferred learning Patterns of students of the University of Hail in Saudi Arabia. To achieve the goals of the study, the two researchers used the descriptive survey method by using the measurement tool of the Learning Patterns Index for Fiedler and Solomon. The results of the study showed that the most preferred learning Patterns among students are (visual/verbal) followed by (sensory/intuitive). The study also showed that there are statistically significant differences at the level of significance $(\alpha \leq 0,05)$ in the values of means and visual-verbal learning Pattern are due to the variable of the school year, and in favour of the level of the first year. The results also showed that there are no statistically significant differences due to the gender variable (male/female). Sasila (2015) conducted a study aimed at identifying the dominating learning Patterns among students of the educational qualification diploma in the Faculty of Education at the University of Damascus and their relationship to their attitudes towards their preparation program. The authors of the paper used the descriptive-analytical method by using data and information-gathering tools (learning Patterns questionnaire and attitudes questionnaire). The results of the study showed that there are statistically significant differences among the mean of the degrees of the members of the research sample on the learning Patterns questionnaire according to the academic specialization variable in favour of the scientific stream students. Al-Rawashdeh, Al-Nawafleh, and Al-Omari (2010) conducted a study aimed at identifying the learning Patterns according to the Hermann model among ninth-grade students in Irbid and its effect on their achievement in chemistry. The results showed that (82\%) of the sample members are of those with a dominant single learning Pattern, while (18\%) of them had two or three Patterns, and the dominant individual learning rate was $(34.5 \%)$ for the interactive Pattern, $(18.8 \%)$ for the internal Pattern, in favour of females, $(14.5 \%)$ for the procedural Pattern, and (14.2\%) for the external Pattern in favour of males. The results also showed that the achievement of the ninth grade students in chemistry varies with statistical significance of $(\alpha \leq 0.05)$ according to their learning Pattern in favour of the internal Pattern. Hailat, Al-Zoubi, and Al-Shdifat (2010) conducted a study aimed at identifying the effect of preferred learning Patterns on self-efficacy among students of the Department of Educational Sciences at Princess Alia College. The two researchers used the descriptive survey method of the Vark
Scale of preferred learning Patterns and Shearer Scale to measure the preferred learning Patterns (auditory, visual, practical/kinesthetic, reading/ writing). The study results showed that the preferred learning Pattern among the sample members was practical/ kinesthetic Pattern, in addition to the absence of statistically significant differences in the degree of self-efficacy due for the learning Patterns and academic year of the study sample members. The female students with a very good and more than a very good GPA are better in the self-efficacy degree than those female students with good and less than good GPA.

Al-Shehri (2009) conducted a study aimed at identifying Patterns of learning and thinking among students of Taibah University. The authors of the paper used the descriptive method by using the tools of data collection and information- the Torrance Scale of (learning and thinking Patterns). The results of the study showed that there are statistically significant differences between the two samples of the College of Science and Education in the degrees of the left hemisphere in favour of the sample of the College of Education, the presence of statistically significant differences among male /female students in the mean of degrees of the left hemisphere in favour of female students, and the presence of statistically significant differences between the two samples of the College of Education and the College Science in the means of the degree of the integrated Patterns in favour of the College of Science group.

Through reviewing previous studies, the authors of the papers noted the interest of these studies in identifying learning Patterns according to the function of the brain, in addition to identifying learning Patterns among school students. What distinguishes the current study from previous studies is that it tried to identify learning Patterns according to the students' use of the senses in the learning process according to the Fleming Model and whether these Patterns differ according to the gender variable, in order to provide faculty members with the results of this study to form a basic criterion for them in choosing teaching and evaluation strategies, to achieve the desired educational outcomes.

\section{Conceptual Framework}

\subsection{The Problem and Questions of the Study}

The observance of learning Patterns among students by faculty members at the universities level is an important and essential factor for achieving quality in the teaching process, which reflects positively on educational outcomes. Based on modern educational philosophies that confirm that the student is the focus of the educational process and the faculty member is the guide and the mentor, it has become obligatory for a faculty member in universities to 
diversify in teaching and evaluation strategies to take into account all learning Patterns among students. Therefore, the study aimed to identify the learning Patterns of students of Al-Shoubak College to make the results that benefit faculty members during the teaching process. The study tried to answer the following questions:

- What are the learning Patterns for students of Al-Shoubak University College?

- Is there a statistically significant difference at the level of significance $(\alpha \leq 0.05)$ in the learning Patterns of Al-Shoubak University students due to the gender variable?

\subsection{The Importance of the Study}

The importance of the current study lies in directing faculty members to detect students' learning Patterns before starting the teaching process. It is hoped that its results will contribute to helping educators and educational policymakers pay attention to students' learning Patterns. The study also contributes to setting and designing a scale for researchers on learning styles of university students, where researchers designed the study tool as a summary of theoretical literature on learning patterns Where he will benefit from this tool researcher in this field.

\subsection{Delimitations and Limitations of the Study}

- The current study was limited to investigating the learning Patterns of Al-Shoubak University College students.

- The results of the study are determined by the characteristics of its sample and the study tool used therein, and by the validity and reliability, it provides.

- The study was conducted in the summer semester of the academic year 2018/2019.

\subsection{The Terminology of the Study}

Learning Patterns: These are the preferred methods and manners for students while teaching courses by faculty members.

Al-Shoubak University College: One of the colleges of Al-Balqa Applied University located in Ma'an Governorate, $225 \mathrm{~km}$ from the capital, Amman.

\section{The Method and Procedures}

Study Method

The study used the descriptive method in its survey form, as it is suitable for the nature of the study.

\section{Study Population}

The study population consisted of students from Shoubak University College enrolled in the summer semester 2018/2019, and their number is (216) male / female.

\section{Study Tool}

To achieve the objectives of the study, the two researchers prepared a questionnaire to measure learning Patterns by reference to previous studies and educational literature.

\section{Tool Validity}

To verify the face validity of the study tool, it was presented in a preliminary form to number of (5) arbitrators from the concerned faculty members in Jordanian universities, to express their views on the relevancy of the paragraphs to the related fields, their clarity and the integrity of their language.

Tool Reliability

The reliability of the study tool was verified in two ways: The first is the internal consistency method using the Cronbach-Alpha equation by applying it to a pilot sample consisting of (10) individuals from the study population and outside its sample, as the total reliability of the tool is (0.90). As for the second method: It was a re-test of the pilot sample with a two-week time interval, where the total reliability coefficient of the study tool is (0.89).

\section{The Criterion of Results Assessment}

To assess the Patterns level, the following criterion was used:

$$
\begin{aligned}
& \text { Range }=\text { Highest Score }- \text { Lowest Score }=3-1=2 \\
& \text { Class Length }=\frac{\text { Range }}{\text { Number of Scores }} \frac{2}{3}=0.66
\end{aligned}
$$

The Pattern level was determined according to the following table:

Table 1. Learning Pattern Level

\begin{tabular}{cc}
\hline Degree & Means Category \\
\hline Low & $1.66-1$ \\
\hline Average & $2.33-1.67$ \\
\hline High & $3-2.34$ \\
\hline
\end{tabular}

\section{The Results of the Study and Its Discussion}

To answer the first question: "What are the learning Patterns of students at Al-Shoubak University College?" The means and standard deviations were extracted, for the study population estimates for each learning Pattern. Tables (2) illustrate these results. 
Table 2. Means and Standard Deviations of Learning Patterns

\begin{tabular}{cccccc}
\hline No. & Pattern & Deviation & Mean & Level & Rank \\
\hline 1 & Visual & 0.64 & 2.39 & High & 2 \\
\hline 2 & Auditory & 0.65 & 2.33 & Average & 4 \\
\hline 3 & Kinesthetic & 0.63 & 2.49 & High & 1 \\
\hline 4 & $\begin{array}{c}\text { Reading and } \\
\text { Writing }\end{array}$ & 0.65 & 2.34 & High & 3 \\
\hline
\end{tabular}

The results that are shown in table (2) indicate that the level of the following learning Patterns (kinesthetic, visual, reading and writing) came in a high degree for the study population and the auditory learning Pattern got the middle degree and the kinesthetic Pattern had the highest mean of (2.49). It was followed secondly by visual learning Pattern with a mean of (2.39), followed lastly by an auditory learning Pattern with a mean of (2.33). The two researchers attribute the result to a set of matters, the most important of which are the following:

- The majors learnt by students are of an applicable, practical nature that requires diversification in the use of all their senses.

- $\quad$ The variety of teaching and evaluation strategies and methods used by faculty members (Critical thinking, problem-solving, investigation, and based on performance) .

- Students' awareness of teaching and evaluation strategies useful to them.

- The nature of the subjects learnt by students, which encourage the use of more than one sense in the learning process.

The means and standard deviations for the population of the study were calculated for the paragraphs of each learning Pattern, and they were as follows:

\section{First: Visual Pattern}

Table 3. Means and Standard Deviations of Visual Learning Pattern

\begin{tabular}{llccc}
\hline No. & \multicolumn{1}{c}{ Paragraph } & Mean & $\begin{array}{c}\text { Standard } \\
\text { Deviation }\end{array}$ & Level \\
\hline 1. & $\begin{array}{l}\text { I learn better through } \\
\text { what I see. }\end{array}$ & 2.78 & 0.54 & High \\
\hline 2. & $\begin{array}{l}\text { I read the things that are } \\
\text { in pictures. }\end{array}$ & 2.47 & 0.625 & High \\
\hline 3. $\quad \begin{array}{l}\text { I remember the shapes } \\
\text { and maps well. }\end{array}$ & 2.38 & 0.57 & High \\
\hline $\begin{array}{l}\text { I lose my patience in } \\
\text { listening to others. for } \\
\text { long periods. }\end{array}$ & 2.32 & 0.729 & Average \\
\hline $\begin{array}{l}\text { I have difficulty listening } \\
\text { to lectures. without other } \\
\text { means. }\end{array}$ & 2.02 & 0.722 & Average \\
\hline & Rate & 2.39 & 0.64 & High \\
\hline
\end{tabular}

Table (3) indicates that the means of the dominant visual learning Pattern among students that came with a high degree ranging from $(2.02-2.78)$. The two researchers attribute this ranking to the fact that the factors linking the centre of perception and learning are more strongly related to direct and repeated observation, and this is evidence that the vision associated with focus makes learning accessible and easier.

\section{Second: Auditory Pattern}

Table 4. Means and Standard Deviations of Auditory Learning Pattern

\begin{tabular}{llccc}
\hline No. & \multicolumn{1}{c}{ Paragraph } & Mean & $\begin{array}{r}\text { Standard } \\
\text { Deviation }\end{array}$ & Level \\
\hline 1. & $\begin{array}{l}\text { I remember a large } \\
\text { percentage of what I } \\
\text { hear. }\end{array}$ & 2.40 & 0.603 & High \\
\hline $\begin{array}{l}\text { I explain the meanings } \\
\text { by listening to the tone } \\
\text { of the voice. }\end{array}$ & 2.40 & 0.644 & High \\
\hline 3. & $\begin{array}{l}\text { I benefit from reading } \\
\text { the texts audibly. }\end{array}$ & 2.38 & 0.614 & High \\
\hline 4. & $\begin{array}{l}\text { I prefer verbal } \\
\text { instructions. }\end{array}$ & 2.28 & 0.643 & Average \\
\hline 5. & I like to talk. & 2.21 & 0.752 & Average \\
\hline & Rate & 2.33 & 0.65 & Average \\
\hline
\end{tabular}

Table (4) indicates that the means of the dominant auditory learning Pattern among students that came with an average degree ranging from $(2.40-2.21)$. The two researchers believe that perhaps human beings, by their nature, are not inclined to learn the audible things, as they are often associated with the character of the speaker, which the listener tired of, and secondly, the audio synonyms of the attendees, often disrupting the main topic due to interference that violates the true meaning.

\section{Third: Kinaesthetic Pattern}

Table 5. Means and Standard Deviations of Reading and Writing Learning Pattern

\begin{tabular}{llccc}
\hline No. & \multicolumn{1}{c}{ Paragraph } & Mean & $\begin{array}{c}\text { Standard } \\
\text { Deviation }\end{array}$ & Level \\
\hline $\begin{array}{l}\text { I have the ability to } \\
\text { understand information } \\
\text { through practical } \\
\text { training. }\end{array}$ & 2.72 & 0.504 & High \\
\hline $\begin{array}{l}\text { I prefer learning } \\
\text { associated with real life. }\end{array}$ & 2.60 & 0.632 & High \\
\hline $\begin{array}{l}\text { I enjoy lessons that } \\
\text { include practical } \\
\text { activities. }\end{array}$ & 2.56 & 0636 & High \\
\hline 4. $\quad \begin{array}{l}\text { I find it difficult to sit } \\
\text { for long periods. }\end{array}$ & 2.38 & 0.696 & Average \\
\hline $\begin{array}{l}\text { I am having difficulty } \\
\text { with theoretical } \\
\text { subjects. }\end{array}$ & 2.22 & 0.708 & Average \\
\hline$\quad$ Rate & 2.49 & 0.63 & High \\
\hline
\end{tabular}

Table (5) indicates that the means of the dominant kinesthetic learning Pattern among students that came with a high degree ranging from $(2.72-2.22)$. The two researchers attribute the reason to the fact that the educational concepts associated with the kinesthetic method take their place in the learner because of the nature of the person who finds that the kinetic echo of the learner 
remains stronger in learning things.

\section{Fourth: Reading and Writing Pattern}

Table 6. Means and Standard Deviations of Reading and Writing Learning Pattern

\begin{tabular}{clccc}
\hline No. & \multicolumn{1}{c}{ Paragraph } & Mean & $\begin{array}{c}\text { Standard } \\
\text { Deviation }\end{array}$ & Level \\
\hline $\begin{array}{l}\text { 1. } \\
\quad \begin{array}{l}\text { I have the ability to do } \\
\text { focused reading and } \\
\text { writing. }\end{array}\end{array}$ & 2.41 & 0.618 & High \\
\hline 2. $\quad \begin{array}{l}\text { Read and understand the } \\
\text { information quickly. }\end{array}$ & 2.39 & 0.643 & High \\
\hline 3. $\quad \begin{array}{l}\text { I love to summarize and } \\
\text { enjoy it. }\end{array}$ & 2.36 & 0.715 & High \\
\hline 4. $\quad \begin{array}{l}\text { I can write all the lectures } \\
\text { I learn. }\end{array}$ & 2.29 & 0.685 & Average \\
\hline 5. & $\begin{array}{l}\text { I have high linguistic } \\
\text { skill. }\end{array}$ & 2.25 & 0.619 & Average \\
\hline & $\quad$ Rate & 2.34 & 0.65 & High \\
\hline
\end{tabular}

Table (6) indicates that the mean of the dominant visual learning pattern among students who graduate from higher education varied between (2.29 and 2.41). This is due, according to the researchers, to the fact that the reading associated with the writing of one's words has greater scientific importance, as a catalyst of the mental power centers, which see that the pursuit of concentration is an important factor of persistence, or that the duration of the speech is longer if it is necessary for written adoration.

The second question: To answer this question that reads "Are there statistically significant differences at the level of alpha $=0.05$ in the learning Patterns due to the gender variable?" To verify the statistical significance of the differences among the means of the study population estimates according to the gender variable, (ONE WAY ANOVA) was conducted, and Table (7) shows the results of the analysis.

Table 7. The one-way analysis of the variance of the effect of gender variable difference on the estimates of the study population (ONE WAY ANOVA)

\begin{tabular}{cccccc}
\hline $\begin{array}{c}\text { Significance } \\
\text { Level }\end{array}$ & $\begin{array}{c}\text { Value } \\
(\mathrm{F})\end{array}$ & $\begin{array}{c}\text { Squares } \\
\text { Mean }\end{array}$ & (DF) & $\begin{array}{c}\text { Squares } \\
\text { Sum }\end{array}$ & $\begin{array}{c}\text { Variation } \\
\text { Source }\end{array}$ \\
\hline 0.703 & 0.624 & 0.221 & 1 & 0.126 & Gender \\
\hline & & 0.156 & 115 & 88.012 & Error \\
\hline & & & 116 & 471.13 & Total \\
\hline
\end{tabular}

Table (7) shows that there are no statistically significant differences at $(\alpha \leq 0.05)$ among the study population estimates due to the gender variable, and the value of $(\mathrm{P})$ (0.624), with a level of significance (0.703), which indicates that the learning Patterns of students do not differ according to gender variable. This may be due to a group of things, the most important of which are the following:

- Students study similar disciplines of an applied nature.

- The diversity of work of students of different genders in all locations.

\section{Recommendations}

The study made the appropriate recommendations according to its results:

- Instruct university faculty members to choose teaching and assessment strategies and methods that take into account all students' learning Patterns, through training sessions and during the semesters.

- Universities should examine each student's learning patterns upon acceptance and document this in his/her identity to be referenced by the faculty member.

- Conducting similar studies on this topic to compare the results (international, regional, etc..).

- Educating students about the different learning Patterns, as an element of curriculums, organizing additional trainings through the semesters.

\section{REFERENCES}

[1] Abu Nadi, Hala \& Shamari, Dhahab \& Shamari, Zainab, (2026). The Preferred Learning Patterns Among Saudi Students Between Reality and Ambition. International Interdisciplinary Journal of Education. Vol 5, No. (5). 217-239.

[2] Al Rawashdeh, Ibrahim \& Nawafleh, Waleed Al Omari, Ali. (2010). Learning Patterns Among Ninth Grade Students in Irbid and their Effect on their Achievement in Chemistry. Jordan Journal of Educational Sciences, Vol 6 No. (4). 361-375.

[3] Al Shahri, Hasen. (2010). Learning and Thinking Patterns Among the Students of Taibah University. Umm Al-Qura University Journal, Saudi Arabia, Al Madina Al Munawara, Vol 1, No. (2), 353-400.

[4] Al-Mahasneh, O., Ayasrah, M., Yahyaa, S., Al-Kriemeen, R., \& Al-Swalha, A. (2020). favorite methods of teaching and evaluation among students in university colleges. International Journal of Education and Practice, 8(2), 365-378.

[5] Almseidein, T., \& Mahasneh, O. (2020). Awareness of ethical issues when using an e-learning system. International Journal of Advanced Computer Science and Applications, 11(1), 128-131.

[6] Dunn, R. \& Dunn, K. (1993). 'Teaching secondary students through their individual learning Patterns: Practical approaches for grades 7-12." Needham Heights, MA: Allyn and Bacon.

[7] Hailat, Mustafa \& Al Zu'bi, Ahmed \& Shdeifat, Nour. (2010). The Effect of Preferred Learning Patterns on Self-Efficacy Among Female Students of the Department of Educational Sciences at Princess Alia College, Jordan, Amman. Journal of Educational Sciences, Vol 1, No. (11), 61-122.

[8] Jaber, Lina \& Quran, Maha. (2004). Learning Patterns the Theory and Application. Al Qattan Educational Research and Development, $1^{\text {st }}$ Floor, Abdulmuhsen Qatan 
Establishment, Ramallah, Palestine.

[9] Jester C. (1998). A Learning Pattern Survey for College: The results of learning Pattern inventory, Retrieved March 5, 2003 from: http://www.metamath.com/multiple/multiple c hoice.cgi.

[10] Kinsella, K. (1994). Perceptual learning Pattern survey. In Reid (1995). Learning Patterns in ESL/EFL Classroom (233-234). Boston: Heinle and Heinle.

[11] Learning Patterns (2002), Retrieved February 20, 2002 from: http://www.unc.edu/depts/ncpts/publications/learnPatterns. htm.

[12] Mahasneh, O. (2020a). A proposed model for the university students' e-portfolio. Journal of Education and e-Learning Research, 7(1), 28-34.

[13] Mahasneh, O. (2020b). The effect of teaching by (mobile learning) in university students's achievement. Paper presented at the Proceedings of the 16th International Conference Mobile Learning 2020, Bulgaria, IADIS.

[14] Mahasneh, O. (2020c). Dataset on perception among male secondary school students on underage smoking in Jordan. Paper presented at the Proceedings of the 16th International Conference Mobile Learning 2020, Data in Brief, 29.

[15] Mahasneh, O. M., \& Murad, O. S. (2014). Suggested model (Related to the Student Portfolio) used in evaluation the students in University Courses. Higher Education Studies, 4(3), 72-81. Available at: https://doi.org/10.5539/hes.v4n3p 72 .

[16] Mahasneh, O. M., Al-Tawarah, H. M., \& Al-Hawartheh, N. A. (2017). The effect of practical presentations' strategy on the achievement of the Ninth Graders students of the Pre-Vocational Education subject in shobak Ddistrict schools. International Education Studies, 10(5), 109-114. Available at: https://doi.org/10.5539/ies.v10n5p109.

[17] Mahasneh, O., Al-tawarah, H., \& Al-Msadeen, T. (2013).
The extent of familiarity and employment of faculty members at Shoubak and Maan University colleges to the strategies and methods of teaching and ways to improve their performance. Ain Shams University Journal, 1(2), $\mathrm{P} 250-300$.

[18] McCarthy, B. (1987). The 4MAT System: Teaching to learning Patterns. Barrington, IL: EXCEL, Inc.

[19] R. F. Voss, J. Clarke. Algorithmic Musical Composition, Silver Burdett Press, Londyn, 1986.

[20] Sasila, Rania. (2015). 'The Dominant Learning Patterns Among Students of the Educational Qualification Diploma at the Faculty of Education at the University of Damascus and their Relationship to their Attitudes Towards their Preparation Program. Arab Universities Association Journal for Education and Psychology, Vol 2.

[21] Steyn, T., \&Marce. J. (2003). A Profile of first-year student learning preferences and study orientation in mathematics Retrieved July 5.2009 from university of Pretoria south Africa, department of teaching and training studies, faculty of education, web site: http//www.math.UDC.gr/ictm2/proc eeding.

[22] Tawarah, H., \& Mahasneh, O. (2020). The reality of university education in Jordan from the viewpoint of faculty members. International Journal of Psychosocial Rehabilitation, 24(8), 7034-7037.

[23] The Australian Flexible Learning (2001), 4-MAT System, Australian National Training Authority, Retrieved May 3, 2001 from: http://flexways.flexiblelearning.net.au/index.jsp.

[24] The Dunn and Dunn Learning Pattern Model of Instruction (2002), Retrieved April5, 2002 from: http://www.unc.edu/d epts/ncpts/publications/learning Patterns.htm.

[25] Zhenhui, R. (2002) Matching Teaching Patterns with Learning Patterns in East Asian Contexts, The Internet TESL Journal for Teachers of English as a Second Language. 8(12), December. 